\title{
Endoscopy Challenges During the SARS-CoV- 2 Pandemic: A Single-Center Experience from Cairo University Hospital-Egypt
}

\author{
MOHAMED B. HASHEM, M.D.; HEDY A. BADARY, M.D.; ISMAIL ANWAR, M.D.; \\ SHERIF HAMDY, M.D.; MOHAMMAD S. ABDELBARY, M.D. and IMAN HAMZA, M.D.
}

The Department of Endemic Medicine, Faculty of Medicine, Cairo University

\begin{abstract}
Background: The coronavirus disease 2019 (COVID-19) pandemic has had a major impact on the daily practice of gastrointestinal endoscopy all over the world. Most endoscopy units had to undergo major adjustments including reducing the numbers of personnel, trainees and postponing a large proportion of endoscopic procedures. We hereby report the daily experience from 15 th of March to 15 th of July 2020 of Kasr Al Ainy Cairo University Hospital Endoscopy unit during the COVID-19 pandemic pre-peak and peak phases in Egypt.

Aim of Study: To study the implications of COVID-19 on the endoscopy unit daily practice and exhibiting the precautions adopted to minimize the risk of exposure to infection.

Patients and Methods: We retrospectively analysed the number of procedures done during the peak of the 1 st wave of COVID-19 pandemic in Egypt as well as precautions used in the endoscopy setting and a comparison was made with the number of procedures done over the previous 4 months and during the same period in 2019 .

Results: During the lockdown, upper endoscopies and colonoscopies accounted for the major differences in number of procedures in comparison to the previous four months prior to the lockdown. On the other hand, the rate of endoscopic biliary drainage did not differ significantly.

Conclusion: During the global COVID-19 pandemic, reorganization of the workflow and the service provided by Kasr Al-Ainy Cairo University hospital endoscopy unit was deemed necessary. Through implementation of strategies aiming at proper patient selection and risk assessment, efficiently reducing the number of working staff, putting off training programs, and applying strict infection control measures, we were able to safely traverse the peak phase of the pandemic in Egypt.
\end{abstract}

Key Words: Endoscopy-Covid-19-Cairo University.

\section{Introduction}

CORONAVIRUS disease 2019 (COVID-19), the global pandemic caused by SARS-CoV-2 has infected more than 3 million people worldwide [1],

Correspondence to: Dr. Mohamed B. Hashem, E-Mail: Mohamedhashem50@ hotmail.com with approximately $20 \%$ of patients developing severe disease and around 5\% requiring intensive care treatment [2]. Due to the ongoing exposure of endoscopists and endoscopy unit nurses to a patient's aerosol during various endoscopic procedures $[3,4]$, the close proximity of the patient to the healthcare providers [5], and the abundance of angiotensin converting enzyme 2 (ACE2) receptors in the duodenal brush border, Endoscopy is considered a high-risk medical activity. Moreover, transmission of SARS-CoV-2 through the faecal-oral route is highly suggested by various recent reports that have confirmed the identification of SARS-CoV2 RNA in stool samples [7,8,9].

Aiming at preservation of medical personnel from infection and at creation of an environment that aids in reduction of SARS-CoV-2 virus spread at our Endoscopy unit, new work organization and patient selection strategies had to be implemented. We hereby describe in this report the first-hand experience from a tertiary Endoscopy Unit, in Kasr Al Ainy Cairo University hospital, Egypt, during the time of COVID-19 pandemic.

\section{Patients and Methods}

\section{Patient selection:}

Since 15 th of March, 2020, in compliance with the general Cairo University Hospital administration plan, the following strategies for patient selection for Endoscopic procedures according to risk assessment has been adopted. With the aim to provide priority to those interventions that can significantly affect patients' survival, all interventions deemed not strictly necessary were postponed. An appropriate triage system was implemented guiding the decision on a case by case basis. All endoscopic emergencies were not to be delayed 
and necessary interventions were performed according to standard emergency endoscopic guidelines, while all elective procedures were deferred.

\section{Results}

\section{Patients' risk assessment:}

Since recent data suggest that the transmission of SARS-CoV-2 mostly occurs before the onset of symptoms [10] every patient was considered a potential carrier of SARS-CoV-2 unless proven otherwise. However, different modalities of individual protection were assigned based on stratification of risk in patients undergoing endoscopic examination. Before entering the endoscopy unit, all patients were referred for medical triage in the ER department and consequently appropriately profiled. Patients were stratified as either confirmed COVID-19 cases, low-risk patients and high-risk patients. Low-risk patients were identified as those without any symptoms during the previous 14 days and no contact with confirmed COVID-19 cases, whereas high-risk patients were identified as those patients who either had contact with a confirmed COVID-19 case and/or who developed one or more symptoms suggestive of COVID-19 during the previous 14 days such as fever, cough, dyspnea, diarrhea or anosmia. Subsequently, high-risk patients were subjected to thorough evaluation and investigations in the form of imaging (CT chest), and laboratory assessment including a complete blood picture with differential cell count, C-reactive protein, $\mathrm{LDH}$, serum ferritin, D-dimer, liver and kidney function tests. After consultation of the hospital's appointed COVID team, SARS-CoV-2 RT-PCR was then ordered whenever indicated. Out of a total of 989 patients, only five confirmed COVID-19 cases were encountered.

\section{Patients management:}

All patients were required to wear surgical masks before entering the Endoscopy unit and to keep it on until the beginning of endoscopy examination. Access to the endoscopy unit was highly restricted where caregivers and family members were not allowed to accompany patients.

\section{Healthcare personnel management:}

Personal Protection Equipment (PPE) were used in all endoscopic procedures. A double pair of gloves, a disposable waterproof surgical gown, a hairnet, a face-shield and disposable overshoes were used in all cases regardless of the patient risk stratification and the procedure performed. However, given that one of the major challenges we faced was the shortage of high-performance PPE, surgical masks were used in most settings while
N95 or FFP2/FFP3 respirators were preserved for confirmed COVID-19 cases and high-risk patients, as well as patients presenting with upper GI bleeding in the Emergency upper GI bleeding room.

In order to minimize the risk of infection, reduce exposure and the need to overuse PPE, the least number of medical staff needed to perform emergency procedures were assigned to attend the department. Training programs were put on hold, and trainees and students were not allowed to attend at the department during the pandemic. The number of attending endoscopists was reduced from a total of 12; including 8 registered endoscopists, with two endoscopists in each of upper endoscopy, emergency GI bleeding, colonoscopy and ERCP rooms, and 4 trainees, one per each room, to 2 registered endoscopists per day performing all techniques simultaneously. Similarly, the number of endoscopy nurses was reduced from a total of 10 per day, 2 in upper GI room, one in emergency GI bleeding room; one in colonoscopy room, 2 in ERCP room, 2 in disinfection and 2 in recovery, to a total of 5 per day; one in one in both upper GI, emergency GI bleeding and colonoscopy rooms, one in ERCP room, one in disinfection, and two in recovery.

Healthcare workers who performed endoscopic procedures on confirmed COVID-19 cases (15 healthcare workers operating on 5 confirmed cases) were all screened for SARS-CoV-2 virus using reverse transcription polymerase chain reaction (RT-PCR) following exposure, and they were all isolated until results were available. They all tested negative at the time.

\section{Endoscopic procedures:}

As mentioned earlier, only emergency endoscopic procedures were performed. The indications varied between life-threatening gastrointestinal bleeding, foreign body ingestion, strictures, ascending cholangitis and other miscellaneous indications.

From 15 th of March 2020 to 15 th of July 2020 (peak of the ${ }_{1 \text { st }}$ wave of COVID-19 pandemic in Egypt), 892 urgent endoscopic procedures on adult patients were done, including 536 (60.08\%) upper endoscopies, $96(10.76 \%)$ performed in the lower gastrointestinal tract, $258(28.92 \%)$ biliary obstruction and ascending cholangitis treated by endoscopic biliary drainage, and two enteroscopy procedures $(0.22 \%)$. In $300(55.97 \%)$ of upper endoscopies, the indication was gastrointestinal bleeding, while there were $46(8.58 \%)$ foreign body removals, 68 $(12.68 \%)$ stricture dilatations, and $122(22.76 \%)$ endoscopies had miscellaneous indications varying 
between persistent vomiting, dysphagia, pre and post-operative assessment, abdominal pain, weight loss and PEG tube insertions (Table 2). Indications for colonoscopies varied between bleeding per rectum, and assessment for colonic masses in most patients, with some patients presenting with other miscellaneous indications such as diarrhea, constipation, abdominal pain, weight loss and followup of inflammatory bowel disease (Table 2). During this time frame, endoscopic procedures were carried out in five $(0.50 \%)$ confirmed COVID-19 cases.

Upon comparing those numbers to the number of procedures performed in the four months previous to the lockdown, and to the corresponding four months in the previous year (Table 1), it was observed that emergency endoscopic procedures constitute around one quarter of the usual capacity of endoscopic procedures in our unit. During the lockdown, upper endoscopies and colonoscopies accounted for the major differences in number of procedures in comparison to the previous four months prior to the lockdown. On the other hand, the rate of endoscopic biliary drainage did not differ significantly. This can be explained by the fact that many of the indications for upper endoscopies and colonoscopies are not urgent in nature, whereas the need for endoscopic biliary drainage is urgent in most instances.

\section{Endoscopy unit layout and recovery:}

During the lockdown period, no physical changes were made in our endoscopy unit layout as none were needed. Our endoscopy unit consists of two floors, with the upper endoscopy and emergency GI bleeding rooms are located on one floor, while the colonoscopy and ERCP rooms are located on the second floor. Due to the reduction in the work flow and the number of patients, it was possible to attain sufficient time spacing between cases. Access to the waiting area was highly restricted, and adequate spacing and social distancing between patients sitting there was ensured at all times. Sufficient time spacing was also ensured between patients in the recovery room.

\section{Conclusion:}

During the global COVID-19 pandemic, reorganization of the workflow and the service provided by Kasr Al Ainy Cairo University hospital endoscopy unit was deemed necessary. Through implementation of strategies aiming at proper patient selection and risk assessment, efficiently reducing the number of working staff, putting off training programs, and applying strict infection control measures, we were able to safely traverse the peak phase of the pandemic in Egypt.
Table (1): Comparison between number of endoscopic procedures before and after lockdown.

\begin{tabular}{lccc}
\hline Procedure & $\begin{array}{c}\text { Number of cases } \\
\text { after lockdown } \\
\text { (15th March - } \\
\text { 15th July 2020) }\end{array}$ & $\begin{array}{c}\text { Number of cases } \\
\text { before lockdown } \\
\text { (15th November } \\
\text { 2019 - 15th } \\
\text { March 2020) }\end{array}$ & $\begin{array}{c}\text { Number of cases } \\
\text { in previous year } \\
\text { (15th March - } \\
\text { 15th July 2019) }\end{array}$ \\
\hline $\begin{array}{l}\text { Upper } \\
\text { Endoscopy }\end{array}$ & 536 & 2519 & 2414 \\
$\begin{array}{l}\text { Colonoscopy } \\
\text { ERCP }\end{array}$ & 96 & 750 & 584 \\
Enteroscopy & 258 & 410 & 450 \\
\hline Total & 2 & 7 & 10 \\
\hline
\end{tabular}

Table (2): Comparison between indications of endoscopic procedures during lockdown period and during corresponding months in the previous year.

\begin{tabular}{ccc} 
Number of cases & $\begin{array}{c}\text { Number of cases } \\
\text { in corresponding } \\
\text { in lockdown } \\
\text { months }\end{array}$ & $\begin{array}{c}\text { months in } \\
\text { previous year } \\
\text { Procedure }\end{array}$ \\
(15th March - & $p^{-}$ \\
15th July 2020) & 15th July 2019) \\
\hline
\end{tabular}

\begin{tabular}{|c|c|c|c|}
\hline Upper Endoscopy: & 536 & 2414 & $<.00001$ \\
\hline $\begin{array}{l}\text { - Hematemesis and } \\
\text { melena }\end{array}$ & 300 & 414 & 0.4762 \\
\hline • Abdominal pain & 22 & 398 & $<.00001$ \\
\hline • Vomiting & 18 & 119 & $<.00001$ \\
\hline • Nausea & 0 & 2 & .157299 \\
\hline $\begin{array}{l}\text { - Pre and post-operative } \\
\text { assessment }\end{array}$ & 2 & 121 & $<.00001$ \\
\hline •Dysphagia & 11 & 70 & $<.00001$ \\
\hline - Dyspepsia & 0 & 15 & $<.00001$ \\
\hline - Strictures & 68 & 80 & .179712 \\
\hline - Weight loss & 5 & 23 & .000175 \\
\hline - Foreign body removal & 46 & 52 & .405383 \\
\hline - PEG tube insertion & 4 & 20 & .000347 \\
\hline $\begin{array}{l}\text { - Assessment of portal } \\
\text { hypertension and } \\
\text { follow-up varices }\end{array}$ & 60 & 1100 & $<.00001$ \\
\hline Colonoscopy: & 96 & 584 & $<.00001$ \\
\hline - Bleeding per rectum & 19 & 102 & $<.00001$ \\
\hline - Weight loss & 2 & 22 & .00002 \\
\hline • Follow-up & 8 & 90 & $<.00001$ \\
\hline $\begin{array}{l}\text { - Pre and post-operative } \\
\text { assessment }\end{array}$ & 4 & 27 & $<.00001$ \\
\hline • Metastatic workup & 0 & 3 & .083265 \\
\hline - Abdominal pain & 10 & 112 & $<.00001$ \\
\hline - Diarrhea & 6 & 41 & $<.00001$ \\
\hline - Constipation & 2 & 52 & $<.00001$ \\
\hline - IBD follow up & 7 & 9 & .505198 \\
\hline • Polypectomy & 0 & 91 & $<.00001$ \\
\hline - Colonic mass & 38 & 35 & 612189 \\
\hline Enteroscopy: & 2 & 10 & .011412 \\
\hline • Melena & 0 & 4 & .0455 \\
\hline - Anemia & 0 & 4 & .0455 \\
\hline • Jejunal thickening & 2 & 1 & .317311 \\
\hline - Duodenal dieulafoy & 0 & 1 & .317311 \\
\hline ERCP & 258 & 450 & 0.5478 \\
\hline
\end{tabular}




\section{References}

1- DONG E., DU H. and GARDNER L.: An interactive webbased dashboard to track COVID-19 in real time. Lancet Infect. Dis., 20: 533-534, 2020.

2- WU Z. and McGOOGAN J.M.: Characteristics of and important lessons from the coronavirus disease 2019 (COVID-19) outbreak in China: summary of a report of 72314 cases from the Chinese Center for Disease Control and Prevention. JAMA, 323: 1239-1242, 2020.

3- JOHNSTON E.R., HABIB-BEIN N., DUEKER J.M., QUIROZ B., CORSARO E., AMBROGIO M., et al.: Risk of bacterial exposure to the endoscopist's face during endoscopy. Gastrointest Endosc., 89: 818-24, 2019. https://doi.org/10.1016/j.gie.2018.10.034.

4- TANG J.W., LI Y., EAMES I., CHAN P.K.S. and RIDGWAY G.L.: Factors involved in the aerosol transmission of infection and control of ventilation in healthcare premises. J. Hosp. Infect, 64: 100-14, 2006. https://doi.org/ 10.1016/j.jhin.2006.05.022.

5- REPICI A., MASELLI R., COLOMBO M., et al.: Coro- navirus (COVID19) outbreak: What the department of endoscopy should know. Gastrointest Endosc., 3/14/2020.

6- WAN Y., SHANG J., GRAHAM R., et al.: Receptor recognition by novel coronavirus from Wuhan: An analysis based on decade-long structural studies of SARS. J. Virol., $3 / 17 / 2020$.

7- YEO C., KAUSHAL S. and YEO D.: Enteric involvement of coronaviruses: Is faecal-oral transmission of SARSCoV-2 possible? Lancet Gastroenterol Hepatol., 5: 3357, 2020. https://doi.org/10.1016/S2468-1253(20)300480 .

8- XIAO F., TANG M., ZHENG X., LIU Y., LI X. and SHAN $\mathrm{H}$.: Evidence for gastrointestinal infection of SARS-CoV2. Gastroenterology E-pub ahea, 2020.

9- GU J., HAN B. and WANG J.: COVID-19: Gastrointestinal manifestations and potential fecal-oral transmission. Gastroenterology E-pub ahea, 2020.

10- HE X., LAU E.H.Y., WU P., DENG X., WANG J, HAO $X$., et al.: Temporal dynamics in viral shedding and transmissibility of COVID-19. Nat. Med., 26: 672e5, 2020.

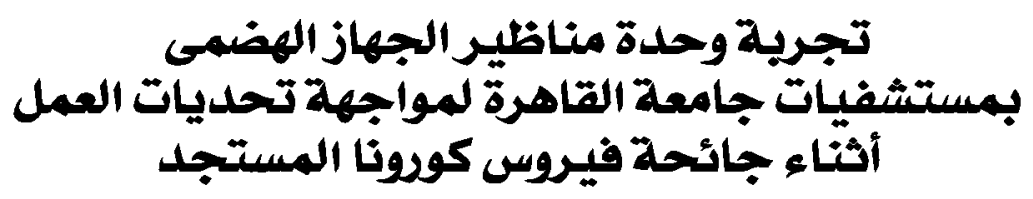

كان جائحة فيروس كويونا الجديد موضوع حديث عالمى منذ انتثاره في مدينة ووهان الصينية أواخر عام 19 . ب وحتى ذوته في جميع أنحاء العالم.

ظهرت أولى حالات الإصابة بفيرس كورنا المستجد فى سوق للحيوانات فى مدينة ووهان المينية، لكن لم يتم تصديد نوع الصيوان الذى نقل العدوى لإلإنسان.

في بداية تفشى فيروس كونونا، انقسم العلماء حول ما إذا كان يمكن أن ينتقل عن طريق الهواء أم لا، لكن تقارير لاحقة من منظمة الصحة

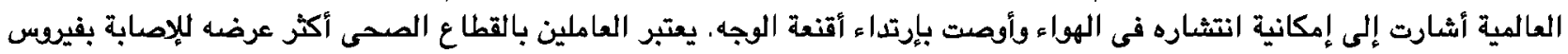

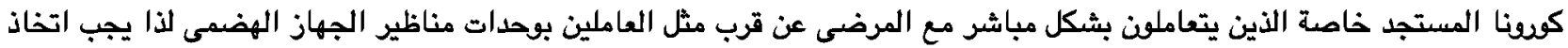

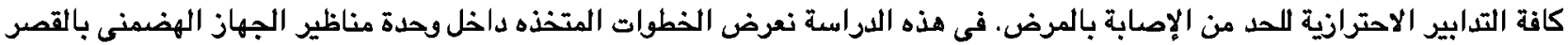

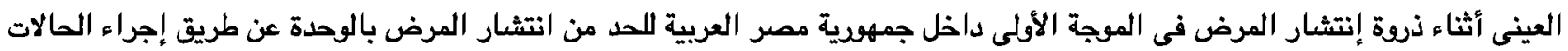
الطارئة فقط، تخفيض علد التمريض والاطباء وجميع العاملين بالوحدة، إيقاف التدريب للاطباء المتدربين بالاضافة إلى توفير جميع ملابس الوقاية لجميع العاملين. 